\title{
The FBI's national DNA database
}

\author{
Russ Hoyle
}

The US Federal Bureau of Investigation's (FBI; Washington, DC) new national DNA database was introduced amid much fanfare by FBI Director Louis Freeh in Washington on October 13. The new database, declared Freeh, should provide "signifcant crime prevention benefit as this new DNA program identifies serial offenders who might otherwise escape detection for their repeat crimes." The new DNA program, added FBI lab director Dr. Donald Kerr, will "allow this exciting technology to reach its full potential in solving violent crimes through nationwide information sharing. ..."

Though the FBI has operated a state and local DNA database in 41 states and the District of Columbia since 1991, the new National DNA Index System (NDIS) will serve for the first time as a repository for hundreds of thousands of DNA profiles of convicted criminals in all 50 states. NDIS profiles will be accessible by police and law enforcement laboratories across the country, allowing speedy tracking of individuals convicted of felony sex offenses and other violent crimes, as well as of crime-scene evidence such as blood, semen stains, or hair.

So far, the seven-year old US system, and a more advanced version in Great Britain, have helped solve an impressive number of crimes by linking crime scenes and identifying criminals, even in cases in which no suspects had been identified. In the US, state and local FBI databases have already produced more than 400 such matches. To date, the states have collected some 600,000 DNA samples and analyzed, or profiled, more than 250,000.

For now, the FBI is not saying what constitutes the "full potential" of the new database-or even how long it will take to become fully operational. One reason is simple enough: The enabling federal legislation, the DNA Identification Act of 1994, sharply circumscribes its lawful uses. To accomodate strict constitutional guidelines for privacy, confidentiality, and lawful search and seizure, the FBI index can only collect genetic information on convicted criminals, crime scenes, and unidentified human remains.

Theoretically, at least, that means the FBI cannot keep a DNA sample or profile from this columnist, or you, or President Clinton, unless we are convicted of crimes. It also means that police or federal agents cannot collect DNA samples from suspects nor even from indicted, not-yet-convicted felons-including terrorists-for investigative purposes. In addition, DNA law also sharply limits DNA identification technology to 13 basic probes that can isolate genetic characteristics, but are unable to provide fuller details of identity, such as hair, eye or skin color.

Though FBI officials will not say it outright, it is likely that as US law enforcement officials gain experience with DNA fingerprinting, monitor the arrest records of less constitutionally constrained police abroad, and track the inevitable advance of DNA identification technology, the 1994 law will rapidly become outdated and need modification. The betting here is that any future amendment of the law will significantly expand the segment of the population from whom DNA samples may be collected and will bring to bear increasingly sophisticated DNA identification technology.

All of this is good news for the biotechnology community. Even now, technical advances, such as phenotypic analysis, in which DNA markers may be used to provide identifying physical, psychological or medical characteristics, are being hotly debated as the wave of the future in criminological circles. In the meantime, because of staffing shortfalls in state and local labs, the massive backlog of offender samples that must be analyzed and profiled, not to mention new biological evidence coming in the door, the development of a full-blown national DNA database is likely to take several years. In that time, the system may well be overtaken by procedural and technological advances.

The natural inclination of law enforcement officials to press for wider latitude in applying DNA identification technology, however, has alerted legal watchdogs and ethicists to possible problems presented by the gathering, storing and utilization of genetic data on criminals. In response, the FBI formed a DNA Advisory Group to oversee establishment of the new database.

Legal challenges have been mounted in 13 of the 50 states aimed at the laws establishing DNA databases, mostly on Fourth Amendment grounds - and defeated in all but one. In Massachusetts, a lower court held that the state database law would allow effectively allow unconstitutional search and seizure of bodily substances. "A bodily intrusion with or without the use of force," wrote the presiding judge, "can only be considered reasonable if probable cause exists to believe the person in question participated in the criminal act for which a. . .sample is relevant evidence."
The decision is being appealed. Nonetheless ethicists have seized on the issue at the heart of the case: Where is the line between coercing citizens to give up bodily tissues that may incriminate them and somehow compelling them to volunteer those tissues legally?

Already, FBI guidelines on the scope of genetic testing have been broadened to include a separate category for juvenile offenders-along with violent felons, burglars, and convicted criminals on parole or probation. Why are juveniles singled out? According to FBI officials, because juvenile crime is increasingly violent, genetic testing might nip criminal careers in the bud, and experience so far has shown that DNA testing has worked well to curb youth crime.

Knotty issues of privacy and confidentiality are likely to continue to plague the stockpiling of genetic data and tissue samples. In fairness, the FBI new national database will store only limited genetic profiles, not samples. But before the system is up and running, simple genetic analysis of that huge backlog of biological samples-which will only increase as time passes-will require storehousing samples in labs across the country.

Though the use of tissue samples for other purposes is forbidden in most states, ethicists point out that pressure not to destroy samples may be considerable, especially from scientific researchers. Indeed, they say exceptions that allow scientific and medical research are common in current state genetic privacy laws. Moreover, from a researcher's perspective, destruction of such a well-defined body of biological samples is "a tremendous waste," as one ethicist concedes.

Still, what happens to samples or data in cases where juveniles records are erased, as happens in many states? What happens when genetic material from a deceased person becomes is requested for an unanticipated purpose, such as genetic research? How do researchers isolate genes indicating a predisposition, say, to criminal behavior without the best available data?

By law, of course, none of this is supposed to happen. For now at least, the federal law enforcement community has fashioned a judiciously circumscribed first step toward a national DNA database that will identify criminals and match them to their crimes. The question of course is whether such a national network will be able to deflect pressures in the future to abuse this powerful new tool in the name of expanding DNA-based law-enforcement strategies. 